UDC 811.111'276.3

DOI https://doi.org/10.32838/2710-4656/2021.4-1/15

Bilenka Yu. O.

Pavlo Tychyna Uman State Pedagogical University

Kolomiiets M. M.

Pavlo Tychyna Uman State Pedagogical University

\title{
FEATURES OF YOUTH COMMUNICATION AND THE USAGE OF DISCOURSE MARKERS
}

The article deals with the current difficulties of understanding different meanings of markers that are used by youth in online and offline communication. Nowadays the spreading of information according to the issue of online communication has become of utmost importance due to the integration of new discourse markers into the world language community. Taking into concideration the continuous process of distance education of COVID-19 reality, a huge amount of students use communicative structures. Consequently, the interpretation of some language units faces many difficulties, as it should be adequate, clear and understandable. There is a need for explanation of some markers that can appear in discourse according to the context, since the language of young people in social life can have a specific vocabulary.

The objective of the article is to show the importance of usage discourse markers during teaching English with teen students.

The major methods applied in this research are the comparative analysis and methods of various Ukrainian and foreign authors' study works and observation method during perceiving different network pages, You Tube, TED Talks and dialogues of younger generation.

The results of the research are defined as an overview of existing discourse markers, that means definitions and classifications in terms of usage in specific communicative situations. We propose the number of vocabulary activities for learners that can improve understanding during communication with native speakers. At the same time, the article presents different examples of markers that can be used and have different meaning according to the language situation. They are presented as being the most usable once in the field of educational purpose.

Conclusions could be revealed as follows. Despite its high popularity and appliance not only in online communication but also in everyday speech, new generation patterns of speech are still cannot be understandable for all the participants of discourse. That is why activities for practicing and using them in every day vocabulary are presented in the article. Finally, there are broad characteristics of youth communication: economy (ellipticity, abbreviations, abbreviations, replacement of letters/ words/parts of words with numbers to save time and speech effort), emotionality (use of emotions). In turn, they confirm that there is a convergence of written and verbal communication in online youth communication that allows young people to create a special kind of online communication.

Key words: discourse, data network, markers, youth word patterns, vocabulary activities, tips.

Introduction. In the age of globalization and information dissemination the notion of "online communication" is of great importance. In our opinion this is a type of communication between individuals through the World Wide Web.

Analysis of recent studies and publications. Our work is devoted to the analysis of discourse markers in English-language youth-online communication. Discourse issues, discourse markers, youth-online communication studies have been addressed by many scholars, linguists, among them: A. Kibrik, G. Jefferson, D. Payar, J. Austin, N. Arutyunova, S. Polyakov, V. Kostomarov, V. Makarov and many others.
In modern linguistics it is possible to organize the works of scientists according to the approaches of studying discourse markers. Thus, the following approaches are distinguished: the oronic approach, which was enlightened in the works of L. Wittgenstein, J. Austin, and J. Sorl; sociological approach presented by the research of Michel Foucault; a pragmatic one, represented by L. Grenoble; ethnographic: S. Stembroke; cognitive: T. van Dijk, B. Dellinger; critical: N. Ferclach; naratologic: Jan Infveret; functional: T. Hunkin.

Problem statement. There are 67 definitions of DM (discourse marker) that can be found. 
We consider the following definitions to be most appropriate: the traditional "broad" interpretation, adherents of which are A. Also, A. Vezhbitskaya, B. Frazer, J. Redecker treat the discourse marker as a linguistic unit whose function is to reflect the coherent relation between a particular expression in a discourse and a previous utterance. Based on the previous definitions, we formulated our own. Discourse markers are an important category of words, with their own characteristics that help to understand the true intentions of the speaker. They facilitate the perception and understanding of the text.

The task of our article is to popularize different forms of discourse markers in communication of youth and propose some ways of using vocabulary activities that will stimulate better understanding of markers.

The objective of the article is to help all the participants of educational process to understand discourse markers in youth communication.

Selection of markers. Criteria for the selection of discourse markers are the following: optionality, immutability, multifunctionality, multigrid, relativity, lack of lexical meaning, close connection with the context.

Selection of discourse markers involves the study of the following parameters: communication of participants, conditions and circumstances of communication, purpose of communication, ways of communication, topics and genres of communication.

In 2020, there were approximately 522 million Internet users worldwide. Thus, as of mid-2020, the largest number of Internet users in Asia is 2, $555,636,255$ people, and the smallest in the islands and Australia - 28, 917, 600. This demonstrates the increasing importance of the Internet network and its large-scale impact on humanity. Although, for obvious reasons, Internet usage is different in the world.

The table presents statistics showing the ratio of Internet users from different parts of the globe, and demonstrates the fact that residents of all continents use the Internet to varying degrees.

The pie chart shows the percentage of the Internet usage.

The Internet Freedom and Broadcast Deployment Act of 2001, adopted at the second part of the

Table 1

\begin{tabular}{|c|c|c|c|c|c|c|}
\hline \multicolumn{7}{|c|}{$\begin{array}{l}\text { WORLD INTERNET USAGE AND POPULATION STATISTICS } \\
2020 \text { Year-Q3 Estimates }\end{array}$} \\
\hline World Regions & $\begin{array}{l}\text { Population } \\
\text { (2020 Est.) }\end{array}$ & $\begin{array}{l}\text { Population } \\
\text { \% of World }\end{array}$ & $\begin{array}{l}\text { Internet Users } \\
30 \text { Sept } 2020\end{array}$ & $\begin{array}{c}\text { Penetration } \\
\text { Rate (\% Pop.) }\end{array}$ & $\begin{array}{l}\text { Growth } \\
2000-2020\end{array}$ & $\begin{array}{l}\text { Internet } \\
\text { World \% }\end{array}$ \\
\hline Africa & $1,340,598,447$ & $17,2 \%$ & $631,940,772$ & $47,1 \%$ & $13,898 \%$ & $12,8 \%$ \\
\hline Asia & $4,294,516,659$ & $55,1 \%$ & $2,555,636,255$ & $59,5 \%$ & $2,136 \%$ & $51,8 \%$ \\
\hline Europe & $834,995,197$ & $10,7 \%$ & $727,848,547$ & $87,2 \%$ & $593 \%$ & $14,8 \%$ \\
\hline $\begin{array}{l}\text { Latin America / } \\
\text { Caribbean }\end{array}$ & $654,287,232$ & $8,4 \%$ & $467,817,332$ & $71,5 \%$ & $2,489 \%$ & $9,5 \%$ \\
\hline Middle East & $260,991,690$ & $3,3 \%$ & $184,856,813$ & $70,8 \%$ & $5,527 \%$ & $3,7 \%$ \\
\hline North America & $368,869,647$ & $4,7 \%$ & $332,908,868$ & $90,3 \%$ & $208 \%$ & $6,8 \%$ \\
\hline Oceania / Australia & $42,690,838$ & $0,5 \%$ & $28,917,600$ & $67,7 \%$ & $279 \%$ & $0,6 \%$ \\
\hline WORLD TOTAL & $7,796,949,710$ & $100,0 \%$ & $4,929,926,187$ & $63,2 \%$ & $1,266 \%$ & $100,0 \%$ \\
\hline
\end{tabular}

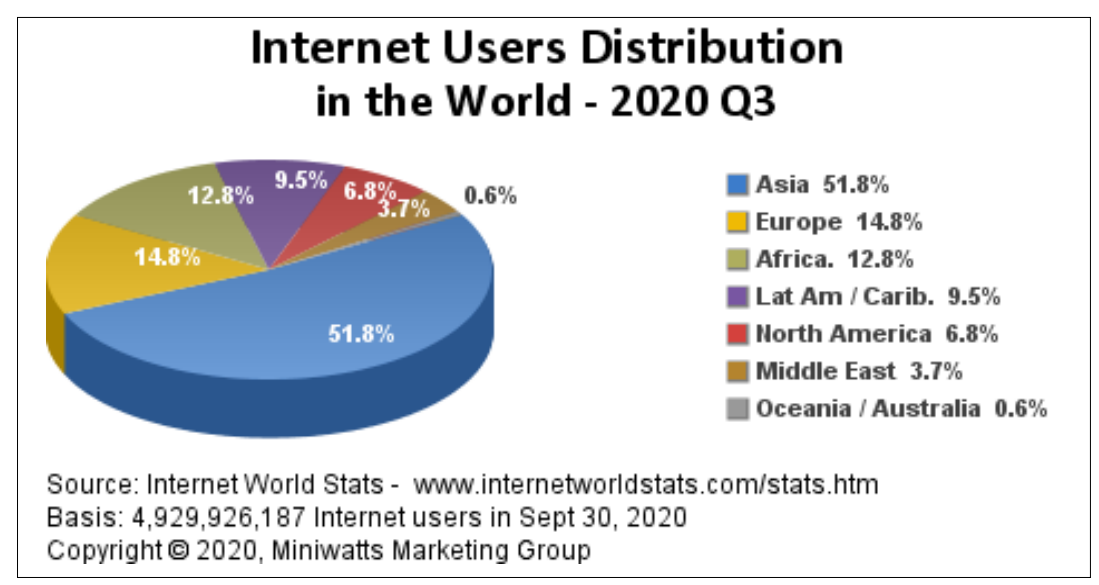

Fig. 1. Internet Users Distribution in the World - 2020 [7] 
$107^{\text {th }}$ session of the United States Congress, outlines the following definition of the Internet: The term "Internet" means the combination of a large number of connected computers and telecommunications, which include the hardware and software that make up the World Wide Web used to transmit information via wired or wireless communications. Thus, the Internet is, first and foremost, the aggregate of the vast number of computer and telecommunication tools connected together, thus forming a single Network. In humanitarian studies, the Internet is viewed through the lens of the functions it performs.

Highlighting such opportunities of the Internet has led to a great interest in linguistics in the study of discourse features of online communication, for example: E. Galichkin, E. Vishnyakova, L. Kovalskaya, N. Akhrenova, O. Dedova, S. Titova, T. Kolokoltseva, V. Kostomarov and many others.

In modern linguistic research, there is no fixed term relating to this type of human communication and there is no unity with regard to the interpretation of the terms proposed. Thus, the following terms can be found in the literature: virtual discourse (O. Lutovinov), computer-mediated communication (K. Shchypitsyn, I. Rosina), electronic communication (E. Galichkin), Internet communication (T. Kolokoltsev) and more.

Obviously, such a diversity of terms in relation to the field of human interaction that are explored due to its novelty and the desire of researchers to introduce something new, different from others in the development of this topic.

As a part of our work, we explore communication, which is defined by us as any interaction of individuals through information and communication resources.

It should be emphasized that we do not use the term "online discourse" when we refer to network communication in the broad sense (we use the term online communication). We use it to describe a specific example of discourse taken from Internet resources.

Social networks are one of the most popular types of online activity. Facebook is the most popular online network based on active use. As of Q2 2020 , there are a total of approximately 1,5 billion monthly active Facebook users, accounting for nearly half of the Internet users worldwide. Connecting with family and friends, sharing ideas, finding entertainment and online shopping are some of the most popular reasons for using the Internet.

Examples of markers. That is why we have chosen online youth communication. This choice greatly facilitated the collection of material for us. We have used some open-ended, open-source communication with the third party observer. As previously stated, in virtual reality it is quite difficult to determine the true age of the subjects, since a person unknown in reality may not be the one for whom he or she pretends to be in the virtual world. However, in order to establish that the real age of the communication participants does not go beyond the names they indicated, and that their mother tongue is English, we looked at their personal pages on social networks. In some cases, we made personal contact with users to conduct the experiment.

While researching youth communication, we were able to identify the following features: the confluence of verbal and written speech, a large number of speech cuts, and emotionality.

Youth communication traces the convergence of oral and written speech not only in terms of content. Written oral spontaneous spoken language is recorded on the Internet. The discourse we have explored in online youth communication most often captures on paper how native speakers of 16- to 19-year-old speak English.

Communication in a youth environment that combines the features of both written and oral communication. Signs of speech in youth communication include the very form of message realization, preservation of the main principles of sentence construction (presence of a predicative group built around the verb), presence of punctuation marks. It is worth noting that sometimes punctuation marks are used in online discourse for a different purpose: to express emotions, to replace words that are often misspelled and sometimes simply missing. However, youth online communication lacks the attributes of writing, such as an expanded system of connecting elements, and sometimes breaks the logical sequence of statements caused by the medium of communication.

The attributes of oral language, which are characteristic of youth communication, include the following: reduction of style, tolerance of grammatical and spelling mistakes, ellipticality, etc. As E. Vishnyakova notes: " $<\ldots>$ in the Internet, written discourse, the language that has always been considered to be the most correct in terms of the norm of the use of linguistic units, undergoes a number of changes that are directly related to the requirements that presents the network as a communicative medium to the design of information: brevity, expressiveness and orientation to the user - the mass addressee". English-speaking youth do not aspire to perceive online communication as a sphere in which the Standard English, General American is used, 
especially in Internet resources, allowing synchronous communication [5].

Sometimes there are signs of a phonetic letter (a type of letter characterized by the fact that a graphic sign, as a rule, indicates a separate sound of a language or phoneme), in other words, often words are written as they are heard. The table "Examples of writing some words and cliches" presents the spelling of words and cliches and their spelling, which are found in online youth communication.

Table 2

Examples of writing some words and cliches used in English-language online communication

\begin{tabular}{|l|l|l|}
\hline $\begin{array}{c}\text { Traditional } \\
\text { Writing }\end{array}$ & $\begin{array}{c}\text { Writing used } \\
\text { in online youth } \\
\text { communication }\end{array}$ & \multicolumn{1}{|c|}{$\begin{array}{c}\text { Application } \\
\text { examples }\end{array}$} \\
\hline Come on & Cmon & Cmon, hurry up \\
\hline Do not & Don't & $\begin{array}{l}\text { Don't tell me what I } \\
\text { did when I was }\end{array}$ \\
\hline I do not know & Dunno & I dunno what to say \\
\hline Going to & Gonna & I'm gonna do it \\
\hline Got to & Gotta & He's gotta pay for it \\
\hline I'm going to & Ito, imona & $\begin{array}{l}\text { Ito leave now. Imona } \\
\text { go to the movies. }\end{array}$ \\
\hline isn't & Innit & Good beer, innit? \\
\hline Kind of & Kinda & She's kinda sick. \\
\hline You all & y'all & $\begin{array}{l}\text { Y'all need to stop } \\
\text { that. }\end{array}$ \\
\hline Love you & Luvu & Luvu, dear. Take care. \\
\hline $\begin{array}{l}\text { As far as I } \\
\text { know }\end{array}$ & AFAIK & AFAIK he did it \\
\hline Building & Bldg & I was in bldg \\
\hline
\end{tabular}

Obviously, this is an incomplete list of such words. However, their fixation brings the convergence of written and clear speech within the framework of youth online communication.

It is also important to note that time imposes some restrictions on online discourse in general. This helped us to highlight another feature of youth online communication - the economy.

The principle of economy in language was formulated by the French linguist A. Martin, who writes: "The term "economy" includes everything: elimination of unnecessary differences, appearance of new differences, and preservation of the existing state. Linguistic economy is a synthesis of acting forces" $[2$, p. 130]. At the same time the principle of economy appears at all levels of speech.

The consequence of economy is the ellipticity of online communication, that is, the use of omissions in the speech or text of a particular linguistic unit, a structural "incompleteness" of syntactic construction.
In our communication study, we find examples of the use of an ellipse, which once again emphasizes our assertion about the convergence of oral and written language in online youth communication.

1. She asked them to help her, they said they wouldn't.

\section{A. Want smth interesting?}

B. Sure. What's that?

Example (1) does not contain information that is easy to understand from the context of the utterance, and example (2) does not contain the "do you" construction that is used to answer the English question, but we clearly understand that this is a punctuation mark at the end of the sentence.

Another feature of online youth communication is the large number of reductions that confirm the economy. Examples of abbreviations and acronyms are explained in the table below.

Table 3

\section{Examples of acronyms and their explanations}

\begin{tabular}{|l|l|}
\multicolumn{1}{|c|}{$\begin{array}{c}\text { Abbreviations } \\
\text { and acronyms }\end{array}$} & \multicolumn{1}{c|}{ Definition } \\
\hline WFH & working from home \\
\hline Chillax & chill and relax \\
\hline ROFL & roll on floor laughing \\
\hline Whatevs & whatever \\
\hline B-day & birthday \\
\hline EVOO & extra virgin olive oil \\
\hline Froyo & frozen yogurt \\
\hline TTYL & talk to you later \\
\hline CUL8R & see you later \\
\hline ASL & age, sex, location \\
\hline B4 & before \\
\hline FYI & for your information \\
\hline IDK & I don't know \\
\hline IMO & in my opinion \\
\hline ORLY & Oh, really? \\
\hline PPL & people \\
\hline
\end{tabular}

The means of linguistic economy are described the help in differentiating users on the principle of "own" / "alien". As part of youth online communication, where people often come together in groups and communities of interest, a friendly atmosphere is firstly created, and people of that age group develop their own style of communication with their own elements so as not to allow strangers into their circle of communication.

Another characteristic of youth communication is its emotionality. In this regard various and often very creative ways of expressing emotions have been developed on the Internet. Obviously, the most striking way to express emotions in online communication is with a smiley 
and an emoticon. From our point of view, the emoticon is able to convey a wider range of emotions, since it is a moving icon and a smile is just a schematic.

The next sign of emotional communication can be considered repetition of letters in emotionallycolored words. Here are some examples:

Reallyyyyyyyyyyy?

Noooooooooo waaaay.

Such spelling also indicates the convergence of oral and written speech in online communication, helping the interlocutor to read the message, opened it in its original form and with the range of emotions of the speaker. Emotions are manifested in letters using punctuation: exclamation points, dots.

It should be noted that the use of exclamation marks for English culture means an extreme degree of emotionality, understood in context: wonder, dissatisfaction and the like.

Question marks can also be repeated if the message participant expresses an extreme degree of wonder sometimes with shades of indignation or exclamation.

1. WTF??

2. Really????

3. Seriously?????

The message in the form of only question marks most often indicates that the participant in the conversation is extremely surprised, shocked and did not understand his interlocutor and/or requires detail, explanation of the message.

A: We broke up.

B: ???????

B: Why? What happened?

A: Stop it.

B: ?????

B: Didn't get it.

A: Stop it.

B: ?????

B: Didn't get it.

It should be noted that the presence of a dot at the end of a sentence in the context of synchronous online communication is most often perceived as the interlocutor who has put it in a mood, is offended or does not want to communicate and tries to end the conversation.

1. I feel it.

2. A: you totally screw it up lol.

B: thanks. I know.

Understanding and analysis of previously presented theoretical material leads educators to the need of creation some practical tasks. There are some various activities that can be done during English classes for better understanding and using markers in speech. We propose some:
- "Create a story" (teacher divides the class into mini-groups or pears and gives different genres to groups (horror, romantic, adventure, fairytale, comedy) using as many as possible discourse markers, and be ready to present it. The rest of the students should guess and comment on the meaning of the discourse markers that are used in the stories;

- "Roleplay a card" (student gets the strip of paper with the first line of situation, place and their characters or roles. They should keep it in secret. Roleplay it, the rest of the group guesses: situation, place and roles;

- "World around us" (video where discourse markers are presented in the speech. Teachers present the video and students name markers and analyse the meaning);

- "Find the one" (one student per lesson finds a song with the usage of new discource markers and present them. Part of students listen to it, after listening they need to present the meaning to the rest with the help of verbal and non-verbal means of communication;

- "On the stage" (students take a strip with the phrase and should present it with the help of nonverbal means of communication, the rest should guess);

- "Do not repeat!" (teacher divides class into two groups, they choose the topic and create the story. The task is not to repeat phrasals in the story of previous speaker);

- "Make a word" (students get several letters of the alphabet, teacher reads the meaning of markers. After it students create a word);

- "Just 20 seconds" (teacher gives board game with lifestyle situations (at the shop, in the cinema, in the hotel, dinner with a partner), students throw dice, get the situation and present markers that can be used in some situations);

- "Synonyms" (replace word or words with discourse markers);

- "Reaction" (the group is divided into two, they create and present 3-4 sentences of situation and other group present the reaction on it using markers).

- During educational process the authors of the article use such activity: at the beginning of the term students are proposed to create a kind of mind map with discourse markers that they will find out during classes. This project lasts for the whole year, at the end they present it.

Conclusions. So, we have highlighted the following characteristics of youth communication: economy (ellipticity, abbreviations, replacement of letters/ words/ parts of words with numbers to save time and speech 
effort), emotionality (use of emotions). In turn, they confirm that there is a convergence of written and verbal communication in the speech process. All this allows young people to create a special kind of communication, characteristic for this age group. There are several tips that teachers should remember:

1. Students should know the meaning of the words or have the possibility of guessing them.

2. There should be the limit of the amont of markers for each theme.

3. Discourse markers should be connected with the topic of the class.

4. The explanation of the task is distinctive and presented shortly.
5. Discourse markers should be up to date.

Distance learning gives the opportunity not only for learning discourse markers but for practising them with groupmates, friends in oral and written communication. The presented activities can be used during all the parts of the lesson as breaking the ice or refresh, when the teacher has several free minutes for lexical activities. As practice shows, students are eager to be a participant of such activities.

As the language is in continuous process of development, appearing of new discourse markers is obvious. New thends demand understanding and correct usage of trendy lexical units.

\section{References:}

1. Amador C., O'Riordan S., Chambers A. Integrating a corpus of classroom discourse in language teacher education : The case of discourse markers. ReCALL. 2006. № 18(1). P. 83104.

2. Karmyzova O. Nekotorye osobennosti tematicheskoj organizacii leksiki komp'juternogo zhargona (na materiale anglijskogo i russkogo jazykov). Jazyk, kommunikacija i social'naja sreda. Voronezh : VGTU, 2012. Vyp. 2. S. 117-131.

3. Martine A. Princip ekonomii v foneticheskih izmenenijah. Moscow : Izdatel'stvo inostrannoj literatury, 1960. $263 \mathrm{~s}$.

4. Sytnikova T. Sushhnost' i specifika komp'juternogo diskursa kak obiekta lingvisticheskogo issledovanija. Vestnik IGLU. Seriya "Filologija”. 2015. № 3. S. 142-149.

5. Shhipicina L. Komp'juterno-oposredovannaja kommunikacija : Lingvisticheskij aspekt analiza. Moscow : KRAS AND, 2010. $296 \mathrm{~s}$.

6. Internet Freedom and Broadcast Deployment Act of 2001. URL: http://www.gpo.gov/fdsys/pkg/BILLS107hr1542rfs/pdf/BILLS-107hr1542rfs.pdf.

7. Internet World Stats. URL: https://www.internetworldstats.com/stats.htm.

\section{Біленька Ю. О., Коломієц М. М. ОСОБЛИВОСТІ МОЛОДІЖНОЇ КОМУНІКАЦІЇ І ВИКОРИСТАННЯ В НІЙ ДИСКУРСИВНИХ МАРКЕРІВ}

У статті розглядаються сучасні труднощірозуміння різних значень маркерів, що використовуються молоддю в інтернеті й офлайн-спілкуванні. Натепер поширення інформачї відповідно до проблеми інтернет-комунікаиії набуває надзвичайної важливості завдяки інтеграчї̈ нових маркерів дискурсу у світову мовну спільноту. Беручи до уваги безперервний процес дистанційного навчання реальності COVID-19, величезна кількість студентів використовують комунікативні структури. Потрібно пояснити деякі маркери, які можуть з'являтися в дискурсі відповідно до контексту, оскільки мова молодих людей у соиіальному житті може мати певний словниковий запас.

Важливість використання маркерів дискурсу під час уживання англійської мови серед підлітків актуальна, беручи до уваги швидкість появи та впровадження нових трендів.

Основними методами, щзо застосовуються в иьому дослідженні, с порівняльний аналіз та методи досліджень різних українських та зарубіжних авторів, метод спостереження під час сприйняття різних мережевих сторінок, Үоитиbе, TED Talks, діалоги молодого покоління.

Результати дослідження визначаються як огляд наявних маркерів дискурсу, їх визначення та класифікаиія з погляду використання в конкретних комунікативних ситуаціях. Нами запропоновано перелік завдань із лексичними одинииями, які можуть покращити розуміння. Водночас у статті представлені різні приклади маркерів, які можуть бути використані та мають різне значення відповідно до мовної ситуаиії.

Незважаючи на високу популярність та застосування не лише в інтернеті, але й у повсякденному мовленні, моделі мовлення нового покоління все ще не можуть бути зрозумілими для всіх учасників дискурсу. Ось чому в цій статті представлені заходи щодо практики та використання ӥх у повсякденній лексиці. Вони підтверджують, що наявна збіжність письмового та вербального спілкування в молодіжному спілкуванні в інтернеті, що дозволяє молодим людям створювати особливий вид спілкування в інтернеті.

Ключові слова: дискурс, мережа даних, маркери, шаблони молодіжних слів, словникова діяльність, поради. 